DOI: 10.14807/ijmp.v12i9.1574

\title{
INTERNATIONALIZATION AND ENGLISH LANGUAGE IN A PUBLIC INSTITUTION
}

\author{
Ayla Colares de Brito Pereira \\ Instituto Federal de São Paulo - campus Suzano, Brazil \\ E-mail: aylabritop@gmail.com
}

Eliana Kobayashi Instituto Federal de São Paulo- campus Suzano, Brazil E-mail: likobayashi@ifsp.edu.br

Submission: $2 / 8 / 2021$

Revision: 2/8/2021

Accept: 5/17/2021

\section{ABSTRACT}

Internationalization is defined as an integration process of international, intercultural or global dimensions with educational purpose and offers. There are many dimensions of educational institutions internationalization from research partnership to international mobility. Among the several requirements for students to participate in exchanging programs promoted by international universities and organizations is English language proficiency. On the other hand the proficiency level requirements can vary according to the mobility programs which set the minimum English level. One example is the SAKURA Science High School Program promoted by the Japan Science and Technology Agency (JST) which selected science and technology students to participate in an exchanging program in Japan. In order to be selected, applicants needed to have B1 (CEFRR) as minimum English proficiency level. Thus this study aims to investigate if Brazilian students of an educational institution have such required level to successfully take part in mobility programs. The qualitative methodology of this research includes documents analysis - internationalization documents and English course program - and questionnaires to students and English teacher. The results show that students are expected to achieve B1 level by the end of high school according to the English subject program. However students believe that they do not have such level in speaking skill which would be one of the main skill in JST program. Most of them classify their level in A2. 
DOI: 10.14807/ijmp.v12i9.1574

Furthermore the English teacher claims that although some students have already achieved B1 or even higher level the majority is at A2.Thus in order to allow more students to participate in mobility programs the institution should invest in extra-curricular English courses to increase study hours and focus more on developing speaking skills.

Keywords: internationalization; language teaching; English proficiency level

\section{INTRODUCTION}

Internationalization is defined as a process of integrating international, intercultural or global dimension with the purpose, functions and offers of education, and can be achieved through the implementation of strategies such as academic programs and research collaborations (Knight, 2003; De Wit et al., 2015). It can also increase low enrolments as well as optimize research output and competitiveness (Ninomiya, Knight \& Watanabe, 2009).

In Brazil, the internationalization process began in the 1970s with actions by the government and institutions to develop the nation through national programs that offered international undergraduate scholarships and research partnership (De Wit et al., 2005). English language plays an important role in the internationalization process considering its position as lingua franca and global language. Therefore most of published information nowadays is in English and it is also the language of instruction (Fonseca, 2016; Finardi \& Rojo, 2015), for example, in Massive Online Open Courses (MOOC) (Finardi \& Tyler, 2015).

One example of internationalization action in Brazil is the student mobility program promoted by Japan Science and Technology Agency (JST) called Sakura Science High School Program (SAKURA SHSP). It offers Rede Federal de Educação Profissional, Científica e Tecnológica students who attend science and technology technical courses a short-term study exchange program in Japan. The requirements to participate involve a graded point average (GPA) of 8 (scale 0-10) and English proficiency level B1 of the Common European Framework of References for Languages (CEFR).

The CEFR is a comprehensive framework developed by the European Council which “(...) provides a common basis for elaboration of language syllabuses, curriculum guidelines, examinations, textbooks, etc. (...)” (CEFR, 2001, p. 1). It consists of six levels that describe what language users are able to do: levels A1 and A2 consist of the basic user, the independent user can be at level B1 or B2 and the proficient user at level C1 or C2. 
The importance of English in this selection process as well as in social and business contexts shows that Brazilian students must use the language in order to successfully compete in the globalized world. Having said it, what needs to be investigated is the expected proficiency level from such students. The JST exchange program sets CEFR B1 as the minimum level which reveals the linguistic profile of the international students.

Thus this study investigated the English proficiency level of students in an educational institution which has participated in selection processes for the Sakura SHSP program. The main objective is to identify the English level of students who attended the third year of high school courses integrated to technical programs in automation and in chemistry areas. Such school year and areas are usually the ones requested by the Japanese exchange program.

Although the educational institution has often participated in the selection process for Sakura since 2018, its applicants have not been successfully classified to take part in the international program so far. According to the results of the last three selection processes, the main issue was the GPA which was higher than the minimum required but lower than the other applicants'. On the other hand, English level seems to hinder the participation of more applicants specially those who have higher GPA but lower English level.

Therefore it is necessary to investigate the students' level and identify the main issues which may prevent them from reaching the CEFR B1 since language is a complex area which demands specific abilities and skills.

\section{LITERATURE REVIEW}

International, intercultural and global form a triad of terms related to internationalization, in which, international is related to the relations between nations, countries and cultures. Intercultural is the diversity of culture within countries, communities and institutions. Finally, global is the world opportunity (Knight, 2003).

The definition established by Knight became, in general, the most accepted but was further complemented by De Wit:

The intentional process of integrating an international, intercultural or global dimension with the purpose, functions and offers of post-secondary education, in order to improve the quality of education and research for all students and staff and to make a significant contribution to the society (De Wit et al., 2015)

According to De Wit et al. (2005) higher education in Brazil went through different phases until reaching the internationalization process. The first phase took place in the colonial period (1500-1822) and was marked by the dominant classes being educated abroad. 
The second era was defined by the opening of Brazilian universities that followed the Napoleonic model of professional training for engineering, medicine and law, with more emphasis on teaching than on research and with an elitist approach.

The third phase began with the university reform of 1968, which was based on the principles of American universities, sending Brazilians abroad to receive advanced training and focusing on administrative efficiency, department structure and on the triad of teaching, research and extension. It was the beginning of the Brazilian internationalization process.

The fourth era started in the early 1990s, and universities followed international trends, higher education policies became more flexible, the system expanded and the quality of universities improved. The internationalization process of higher education started as a result of the actions of the government and institutions in order to develop the country. Internationalization was seen as an attempt to revolutionize universities and strengthen Brazilian higher education. This process reached more significant results in the 1970s with the national programs that offered scholarships and degrees abroad and joint research, aiming at exchanging of knowledge and specialists.

In the last decades, the internationalization process has been growing and most institutions, both public and private, offer programs in a foreign language (usually in English), joint research and distance education and teleconferencing. However, this growth generally follows market trends and a world dominated by the strongest universities universities in English-speaking countries like the United Kingdom, USA, Canada and Australia -, generating low quality standards (de Wit et al., 2005).

According to UNESCO (United Nations Educational, Scientific and Cultural Organization), academic institutions around the world have social responsibility to assist in the development of scientific knowledge. So the universities activities play a fundamental role in the integration between nations through the internationalization process.

Cunha-Melo (2015) claims that there are different degrees of internationalization which can be evaluated and measured through the following indicators: budget coming from other countries; budget coming from other countries and generating results; international coauthorship in publications; recruitment of researchers from other countries; international mobility; budget for collaborative research programs or projects; interactional use of own structure and; evaluation procedure. Therefore, internationalization aims at the following goals: broadening territorial and ethnic approaches; make scientific research data available 
across the national border; and identifying promising research areas to help increase knowledge (Cunha-Melo, 2015).

An example of a Brazilian program that aimed at international mobility was the Science without Borders (Ciências sem Fronteiras) conducted by the Ministry of Science, Technology and Innovation and Ministry of Education. It was the largest internationalization initiative and offered more than one hundred thousand scholarships especially to undergraduate students of Brazilian public universities. However the English level of the applicants became an obstacle to the successful implementation of the program.

Another example of the importance of English for internationalization is the Japanese SAKURA Science High School Program (SAKURA SHSP) which aims to promote a shortterm exchange in Japan for Brazilian students in advanced science and technology fields. Although the program is in a Japanese speaking country, the applicants are required to have intermediate English level and Japanese language is not a requirement.

Having said it, English as lingua franca (Kahane \& Kahane, 1976; Firth, 1996; Crystal, 2003; Seidlhofer, 2005) has played a pivotal role in internationalization for decades. As Fonseca (2016), Finardi \& Rojo (2015) point out Brazilian higher education institutions are trying to get more internationalized and English is commonly used in publications and as a medium of instruction. For example, Finardi and Tyler (2015) showed that most of the educational MOOC courses (Massive Online Open Courses) that are aimed at a broad audience are offered in English. However, Brazilians still find difficulties in English learning, especially in speaking skills since some sound of the English language do not exist in Portuguese (Pontes \& Davel, 2016; Trevisol, 2014).

\section{METHODOLOGY}

This investigation is a case study which was conducted in an educational institution located in Great São Paulo. Students and the English teacher of two classes of the third year of high-school integrated to technical courses - Chemistry and Industrial Automation - were the participants of this study.

The official documents related to the institution's internationalization policy are analysed, such as the SAKURA Science High School Program (SAKURA SHSP) public calls from the IFSP $N^{\circ} 165 / 20181$ and $N^{\circ} 88 / 20202$ and the CONIF/AI 01/20193. In addition, the

\footnotetext{
${ }^{1}$ Available in: https://www.ifsp.edu.br/images/pdf/Noticias/Chamada-n-165-2018 Programa-Sakurade-Cincia-para-o-Ensino-Mdio-1.pdf. Access: 20-05-2020
} 
DOI: 10.14807/ijmp.v12i9.1574

course program that guides the high- school integrated to technical course in automation 4 and in chemistry5 as well as the English language subject program are discussed. The analysis of these guiding documents aims to understand the specificities of the English proficiency level.

Questionnaires were applied to the students and the teacher. To the former a Likert scale questionnaire was used to identify the participants' opinions on their own ability to use the language, for example, the most used language skills, contexts of use, lexical knowledge, among others. To the latter a questionnaire with closed and open items was applied to know the teachers' view on students' proficiency and skills.

\section{RESULTS}

In this section the analysis of the documents and the questionnaires data is presented.

\subsection{Official internationalization documents}

There are underlying assumptions concerning the English abilities and skills expected from the exchange students in the IFSP $N^{\circ} 165 / 2018$ and $N^{\circ}$ 88/2020, and CONIF/AI 01/2019 calls of the SAKURA SHSP. The schedule of activities available in the documents includes visits to universities, institutes, high schools, museum and Tokyo and Nagano cities. There are also cultural activities, lectures with Nobel Prize winners, oral presentations among other activities with Japanese and foreign students.

To participate in this short-term exchange, students must be enrolled in exact sciences or agronomy courses, according to the public calls of 2018 and 2020, or in courses of the following axes: control and industrial processes, information and communication, infrastructure or industrial production, according to the 2019 call. In the three documents, applicants are also required to have at least B1 level of the CEFR.

Considering the activities the exchange students will participate in, it is possible to conclude that the most used English skills are listening and speaking since they must understand lectures, interact with people from other countries, carry out presentations, attend classes and other activities that mainly require these two language skills.

\footnotetext{
${ }^{2}$ Available in: https://www.ifsp.edu.br/images/pdf/Arinter/EditalSakura_2020_V1.pdf. Access: 20-05-2020

${ }^{3}$ Available in:

http://portal.conif.org.br/images/20190815_Sakura_Program_2019_publica\%C3\%A7\%C3\%A3o.pdf. Access: 20-05-2020

${ }^{4}$ Available in:_http://szn.ifsp.edu.br/portal2/arquivos/artigos/735/ppc_automacao_integrado.pdf. Access: 20-052020

5 Available in: http://szn.ifsp.edu.br/portal2/arquivos/artigos/374/ppc_quimica_integrado.pdf. Access: 20-052020
} 
Thus, considering Sakura internationalization program specifically, it seems that the third year of high school students need to be able mainly to speak and understand English according to the contexts and demands required from the exchange students. This does not mean that reading and writing skills are not relevant in the process, but listening and speaking are fundamental.

\subsection{The English course program}

The analysis of the Automation and Chemistry programs focused on the learning objectives of the English subject which were compared to the CEFR levels. High school is comprised of three academic years and English is a mandatory subject in all of them.

The content and learning objectives of the first year are the same for both courses and show that students are expected to be able to use English at the CEFR basic level. It means to know how to greet, introduce themselves and others and ask and answer questions about their lives such as where they live. The program also includes expressing intentions, plans and predictions and simple sentences use to write personal matters such as family, educational background, profession/work, etc. These abilities match the A1 and partially the A2 level.

The second year syllabus includes interview, a genre which is described in CEFR A2 level. The language user is able to understand and communicate ideas and information in order to take part in interviews. This genre is also in B1 level but in a deeper approach since the user is expected to show some initiatives and to be able to conduct it using a prepared questionnaire. The course program also includes the ability to communicate via social networks, write text messages and know how to give reasons and opinions, which are similar to the abilities described in B1 level such as to write notes and messages with everyday content and language.

In the third year students are expected to make comparisons, express conditions and discuss topics like food in the world, health, intelligence and skills, art and technology. According to CEFR, comparisons and contrast is a B1 skill, and both, understanding and expressing conditions and warnings, as well as discussing family topics and contexts like food and technology, are also at B1.

Therefore, according to the course program, the student should reach B1 level by the end of the third year. However, it is observed that the document does not clearly set a proficiency level to be reached. In addition, the program does not divide the learning objectives in skills like speaking, listening, writing and reading as the CEFR does with 
INDEPENDENT JOURNAL OF MANAGEMENT \& PRODUCTION (IJM\&P)

http://www.ijmp.jor.br

v. 12, n. 9, Special Edition, December 21, IFLOG 2020

ISSN: 2236-269X

DOI: 10.14807/ijmp.v12i9.1574

detailed descriptions. On the other hand, the program shows a more modern language view focused on language use and no longer focused entirely on structure and form.

\subsection{Questionnaire to the students}

Thirty six students answered the online questionnaire, twenty one from Chemistry course and fifteen from Automation. The number of students in each class is 40 and 50 respectively. The questions were related to specific abilities: writing, reading, listening and speaking skills from B1 CEFR.

There were not significant differences between the two groups except in three questions. For this reason, most graphs show the results with students from both courses together.

Concerning the writing skill, most students agreed, partially or totally, that they can make simple notes during a seminar or class in English and write a simple text for a friend telling about their experiences (Figure 1). However, regarding the ability to write a short and simple essay on subjects that interest them, most students of the Integrated Chemistry Technician agreed that they can do it, while the responses of the Industrial Automation's students were more distributed among the alternatives of the question as it is shown in Figure 2.

Most students totally agree and partially agree that they are able to write a simple text to a friend telling about their experiences, describing the feelings and reactions they had (Figure 3).

Thus 65\% of the students' writing skill can be classified in the CEFR B1 level while $35 \%$ are not confident about it and could be placed at A2 level.

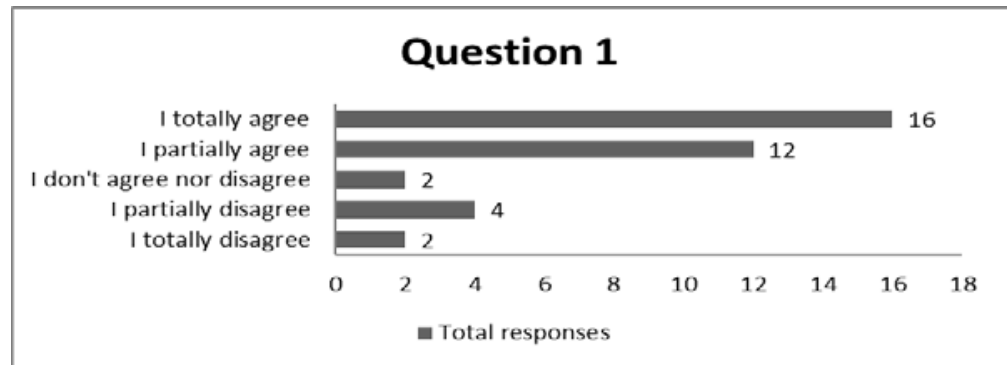

Figure 1: Degree of agreement with the ability to make simple notes during a seminar or class in English 


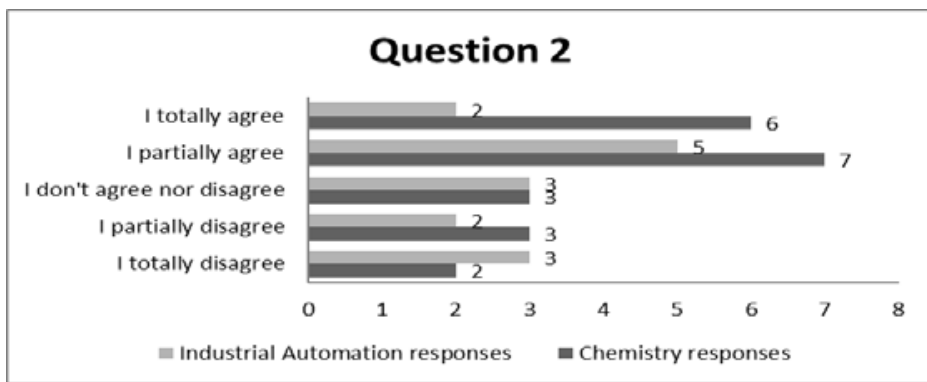

Figure 2: Degree of agreement with the ability to write a short and simple essay on subjects that interest the students

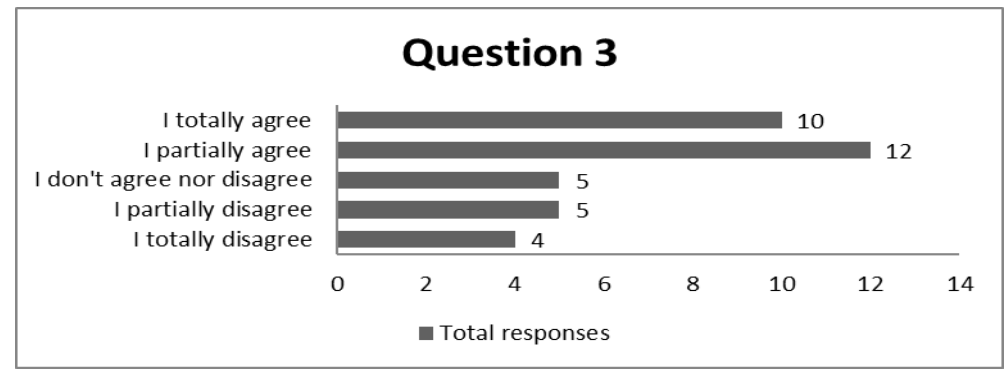

Figure 3: Degree of agreement with the ability to write a simple text to a friend telling about their experiences, describing the feelings and reactions that the students had

Regarding the listening skill, most students, both in Chemistry and Industrial Automation, selected the alternatives “totally agree” or "partially agree”, stating that they can understand the main ideas of radio or TV programs in English, lectures, classes and people talking about current issues, their daily lives and their interests (Figure 4). In addition to it, they can understand a well-structured lecture/class in English that addresses familiar topics (Figure 5). Similar results were obtained concerning their ability to understand people talking about every day or work-related subjects as long as they speak in an accent students are familiar with (Figure 6).

Therefore $69 \%$ of the students claim that they can perform listening activities related to B1 level. 31\% can be classified in A2 as such participants believe they are not able to understand the presented listening situations.

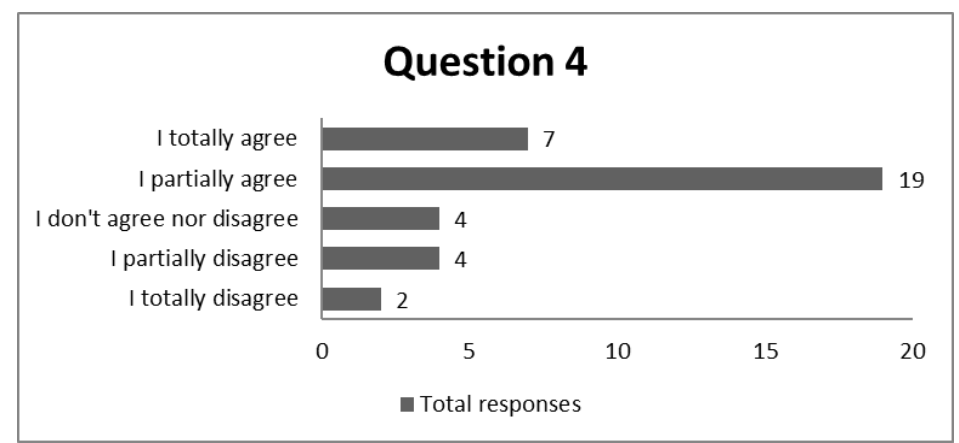

Figure 4: Degree of agreement with the ability to understand the main ideas of radio or TV programs in English that address current issues or students' personal/professional interests 
DOI: 10.14807/ijmp.v12i9.1574

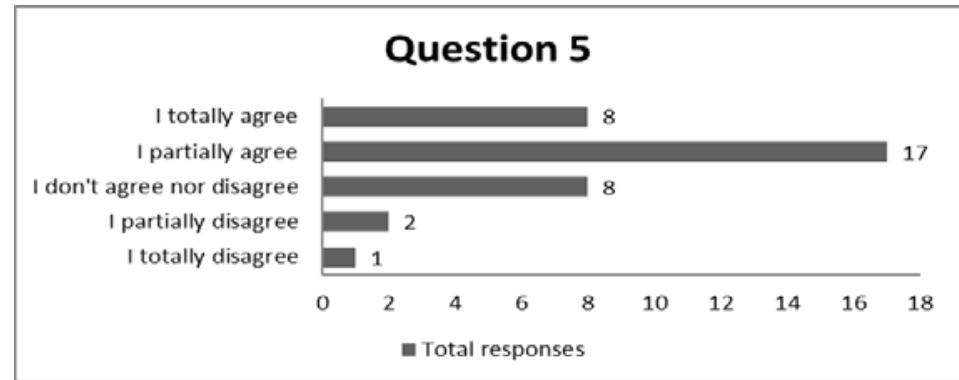

Figure 5: Degree of agreement with the ability to understand a well-structured lecture/class in English that addresses familiar topics

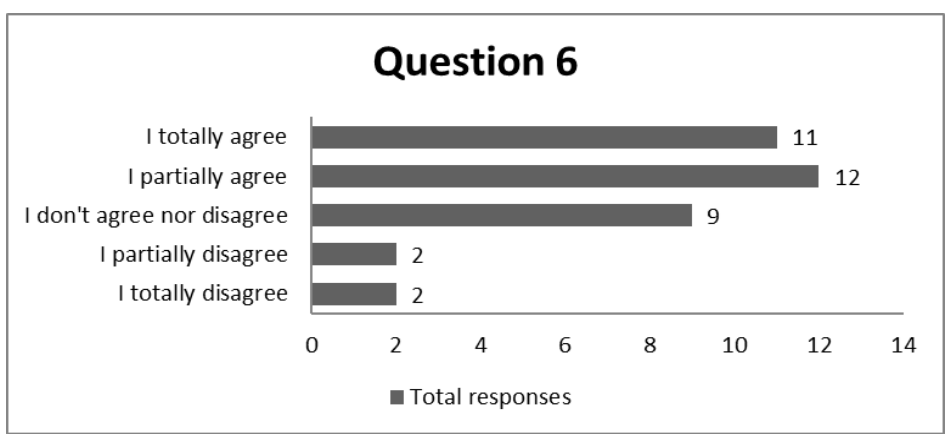

Figure 6: Degree of agreement with the ability to understand people talking about every day or work-related subjects as long as they speak in an accent students are familiar with

As for the reading skill, most students also agreed, partially or totally, that they can understand texts and newspaper articles written in English that use everyday language and approach subjects of their interests and infer the meaning of an unknown word by the context (Figures 7 and 8). Participants also seem to be able to understand specific newspaper genres as long as their topics are familiar (Figure 9).

Such results show that $74 \%$ of the students claim they can perform B1 activities while $26 \%$ can be classified in A2 level.

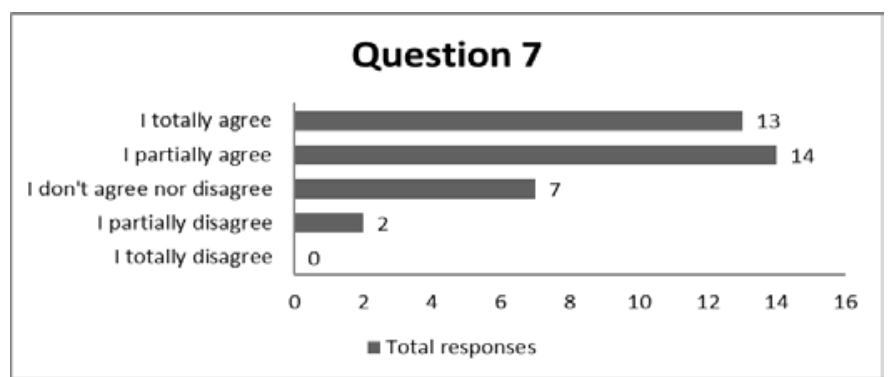

Figure 7: Degree of agreement with the ability to understand texts written in English that use everyday language 
DOI: $10.14807 /$ ijmp.v12i9.1574

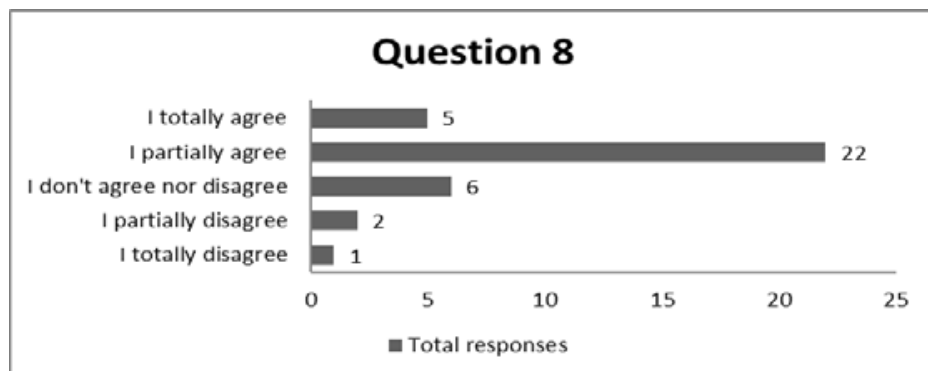

Figure 8: Degree of agreement with the ability to deduce or infer the meaning of an unknown word in English by the context of the text

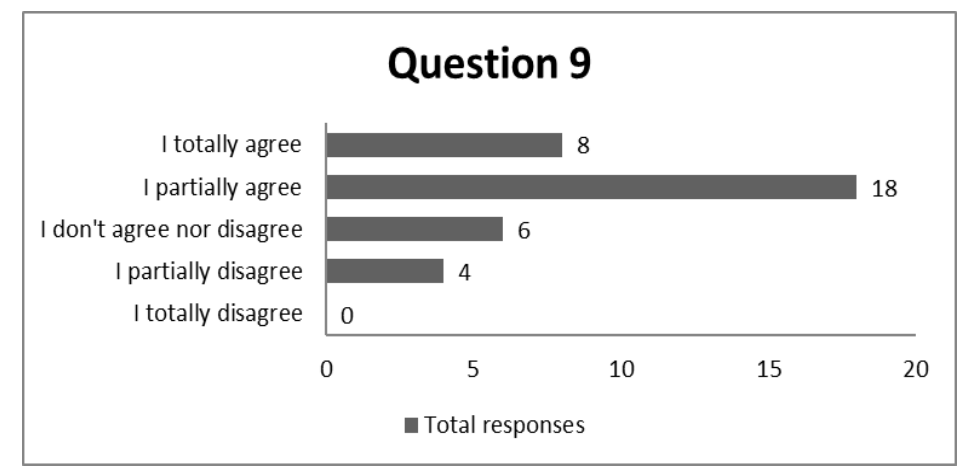

Figure 9: Degree of agreement with the ability to understand written articles in newspapers that address students' subjects of interest

Concerning the speaking skill, few students totally disagreed that they can describe objectives, hopes and ambitions (Figure 10). However, regarding the ability to have a conversation in English about things in their daily lives or their interests, most students did not agree nor disagree, but the responses of the Industrial Automation's students were more distributed among the alternatives of the question as it is shown in Figure 11.

Most students totally disagreed and partially disagreed that they are able to tell a story or comment on a plot of a film or book, describing the emotions and reactions they had (Figure 12).

Therefore $42 \%$ of the students claim that they can perform speaking activities related to $\mathrm{B} 1$ level, while $58 \%$ of the participants can be classified in A2.

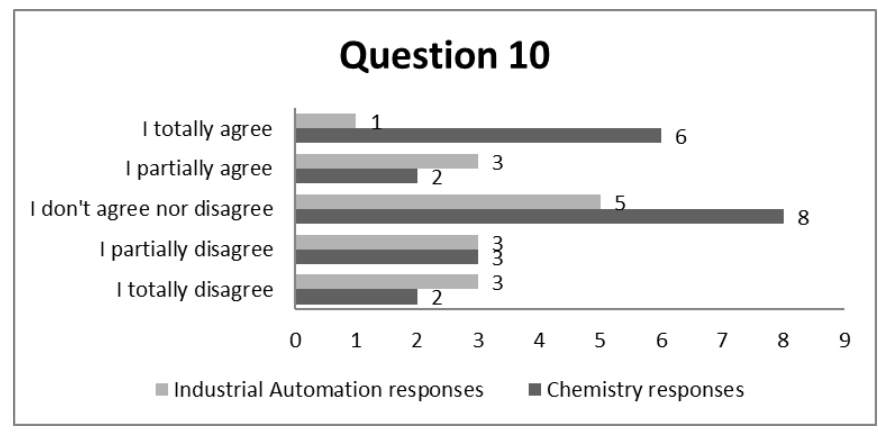

Figure 10: Degree of agreement with the ability to have a conversation in English about things in the student daily life or interests 


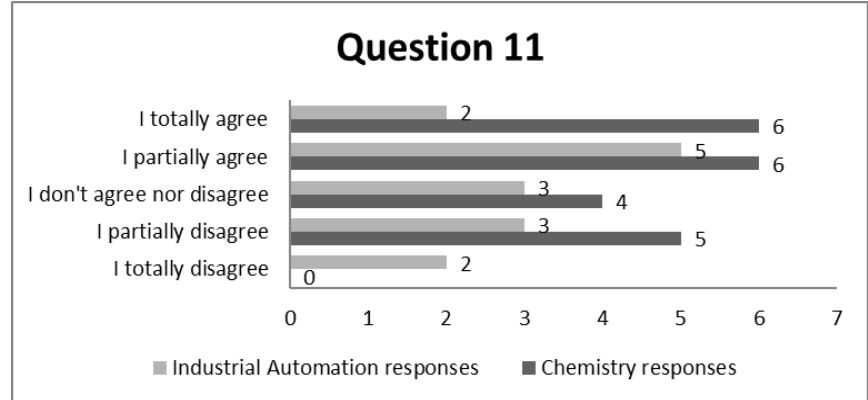

Figure 11: Degree of agreement with the ability to describe goals, hopes and ambitions in English

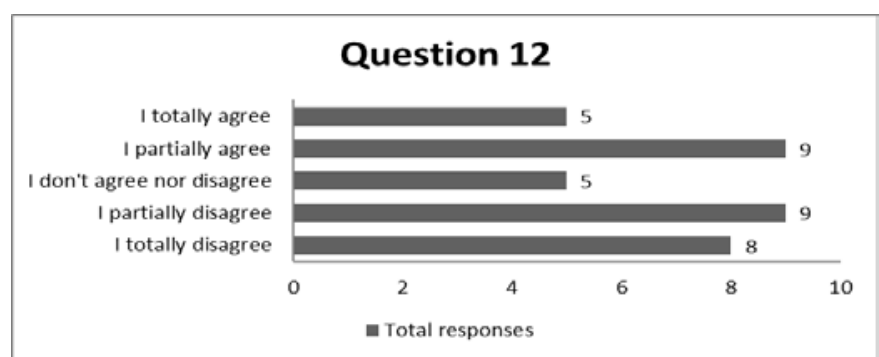

Figure 12: Degree of agreement with the ability to tell a story in English or comment on the plot of a book / film describing emotions and reactions

\subsection{Questionnaire to the teacher}

The online questionnaire applied to the teacher had questions similar to the one applied to the students, some specifically related to CEFR and the JST internationalization program and three open questions about the English level of the students. The participant has taught both classes - Chemistry and Automation - for almost two years. Since the teacher claimed that the groups have achieved very similar marks in English subject and they perform similarly in class, the questionnaire was answered considering both groups.

The Figure 13 shows that more than $75 \%$ of the students can write three different genres: simple text to a friend, a short essay and class notes. These questions covered abilities from A2 and B1 levels according to CEFR. Thus in terms of writing skills the teacher believes most students' level is B1. 


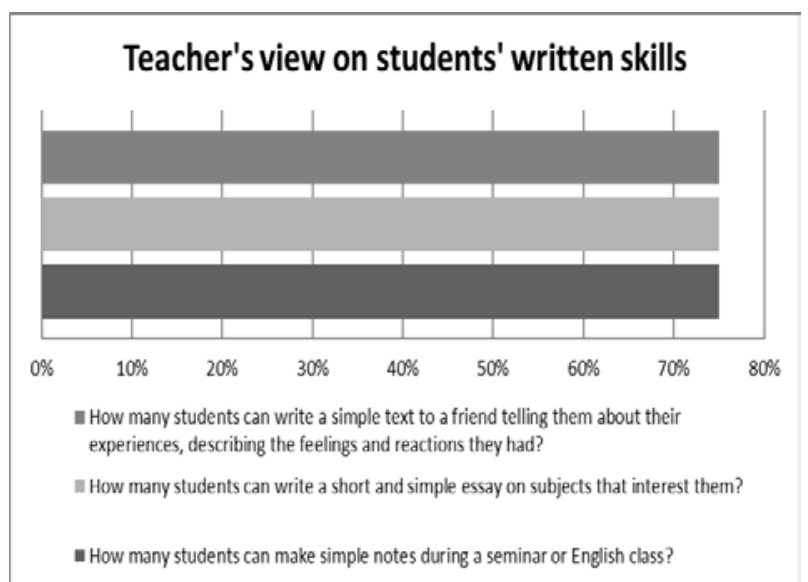

Figure 13: Teacher's view about the percentage of students that are able to write in English

Concerning the listening skill, the participant points out that $75 \%$ of the students can understand daily conversation and well-structured classes both of them about familiar topics. On the other hand understanding TV or radio shows about students' interests is seen as a more complex activity and 50\% of the students would be able to do it (Figure 14).

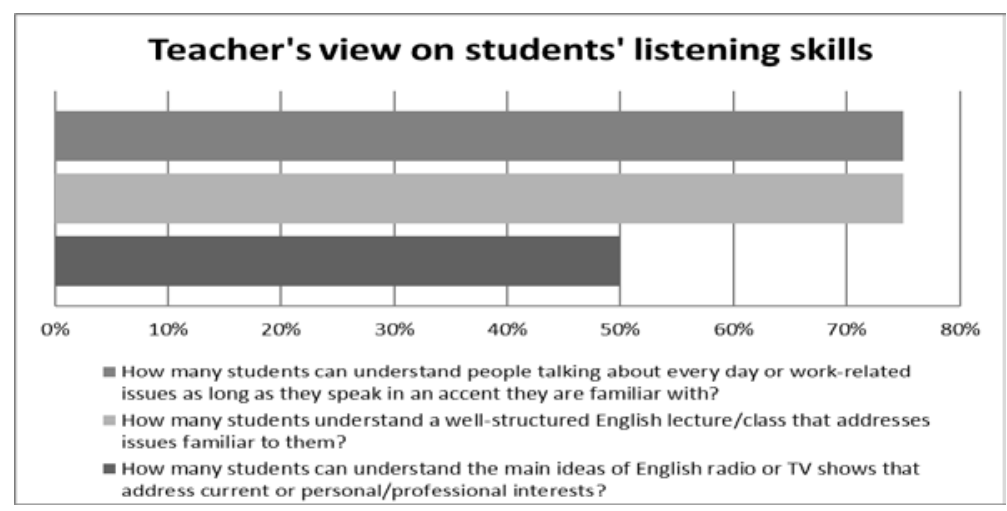

Figure 14: Teacher's view on students’ listening skills

Similar results were achieved in reading skill as most students can understand texts written in an everyday language which is also expected at A2 level. However half students can deal with a more complex text like a newspaper article and 75\% of them have developed the strategy to grasp words meaning by the context. Therefore in terms of reading skill the teacher believes most students' level is B1 (Figure 15). 


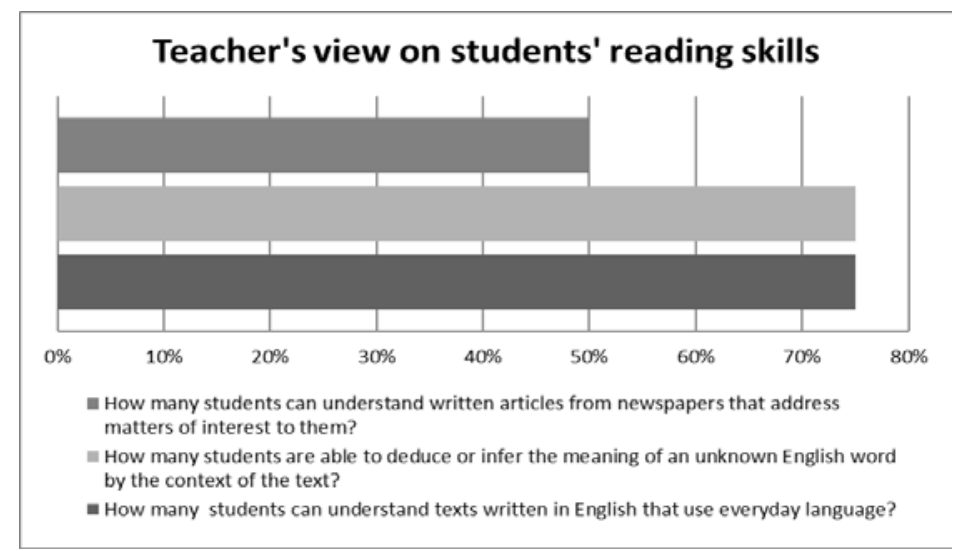

Figure 15: Teacher's view on students' listening skills

Speaking seems to be the most challenging skill as $50 \%$ of the students can perform more complex activities like describing movie plots and commenting on them as well as express their goals and ambitions. On the other hand most students, 75\%, can hold conversations on daily and familiar topics.

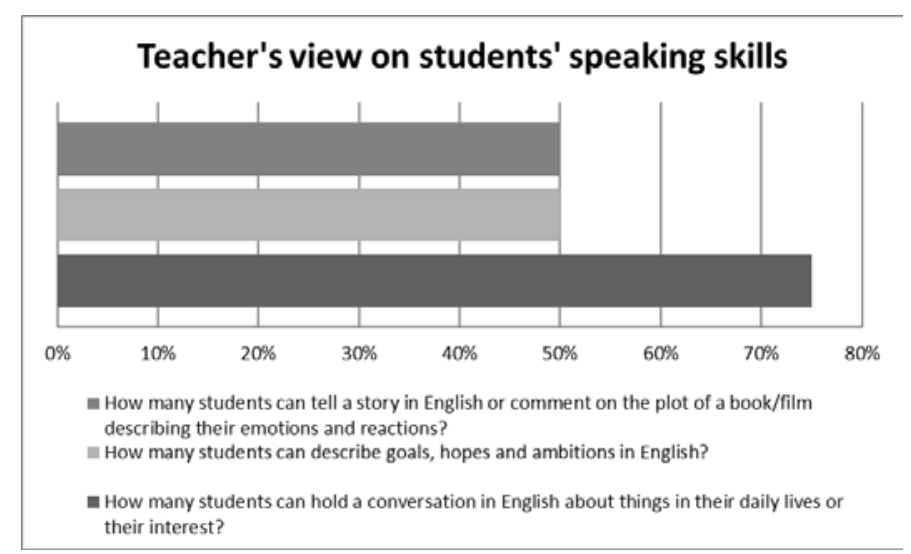

Figure 16: Teacher's view on the percentage of students that are able to speak in English.

The teacher also claims to know the English requirement set in JSP exchange program. However in her opinion most students level in the third year is still A2 although there are also students at B1 or even higher.

\footnotetext{
“(...) the level of understanding and production of most students is characterized by familiar contexts and concrete everyday situations. Consequently, they are able to use expressions and grammatical constructions required in these scenarios, which would classify them at A2 level. (...)
}

Thus the teacher's answers show that students can perform better in reading, writing, listening and speaking activities which are related to very familiar and concrete situations and to well-known genres. For this reason, newspaper articles and TV shows which may bring more complex vocabulary and faster speaking may be more difficult to be understood by the students. When asked about what makes it difficult for students to be at level B1, the teacher replied that "Level B1 requires a greater command of the language that goes beyond the 
DOI: 10.14807/ijmp.v12i9.1574

scope of concrete and allows expressing more abstract and imaginary situations. (...)”. Although the percentages of students who can use the language in the presented situations are high in most of the questions, it is safe to say that the teacher thinks that those situations which demand a higher level of English or others which she may have worked in class are key to classify students in B1 level.

Considering the institution internationalization and the English language requirements, the teacher emphasizes the importance of increasing study hours, more contact with the language outside classroom, use of technology to learning autonomy and extracurricular courses:

“(...) that those students who are still in A2 dedicate more hours of study outside the classroom and increase contact with the language. This reflects a more autonomous learning, in which the student can use the various technological resources to which he is already used to in favour of his development (...). On the other hand, it would be important for the campus to offer extra-curricular courses, to apply international proficiency tests and to promote language use situations (...).”

Despite the fact that in general most students' English level is lower than the one set by the JSP program, there are several ways to help them improve their skills. On the other hand some students have already reached B1 level and others are on the way to. Speaking skill development seems to be the main priority now.

\section{DISCUSSION}

As discussed by Fonseca (2016), Finardi \& Rojo (2015) and Finardi \& Tyler (2015), this study also proved the relevance of English language in the internationalization of a public educational institution. Firstly, the language requirements were analysed through three documents: the public calls IFSP $\mathrm{N}^{\circ}$ 165/2018 and $\mathrm{N}^{\circ}$ 88/2020 and CONIF/AI 01/2019. Although the documents require CEFR B1 as the minimum proficiency level, there were not linguistics specifications such as the most used skills. However the results of the analysis showed that speaking and listening are probably the most required skills according to the events, duties and participants involved in the exchange program.

According to CEFR, the speaker of level B1 is able to understand speeches with standardized language and to have a conversation about everyday matters or of his/her interest. Therefore, the level B1 speaker will be able to enjoy, in general, the activities that are offered by the program, and may find it difficult to understand oral speeches that have an accent that the scholarship holder is not familiar with. 
The English subject programs of the Automation and Chemistry courses showed that students are expected to develop language skills and abilities which range from CEFR A1 to B1 along the three-year high school course. Thus based on such programs and the English language requirements of the JST Sakura exchange program, students would be theoretically qualified to participate in that internationalization selection process.

Nevertheless the results of the questionnaire applied to the students showed that one of the main English skills to perform adequately in the exchange program is the most challenging one in their opinions. $44 \%$ of the students think they can not speak at B1 level. However concerning their listening skill, $69 \%$ are able to perform according to the B1 expected abilities.

In addition, the teacher confirms that most students would face difficulties speaking at B1 level in the third year as well as understanding more complex aural texts. Therefore the results point to speaking as the most challenging skill, similar to other studies developed in English learning area (Pontes \& Davel, 2016; Trevisol, 2014). Besides while the teacher believes students are mostly at A2 level in terms of general skills and abilities most students classify themselves at B1 level.

These different views on language proficiency levels can lead to the conclusion that most students think they have achieved the objectives set in their English subject program in a broaden way whereas the teacher believes that there is room for improvement especially in speaking and listening skills. Despite these contrasting perspectives, students and teacher are aware of the difficulties in speaking, one of the fundamental skills required in the SAKURA SHSP program. Such result shows that English may still be an obstacle for Brazilian students to successfully participate in internationalization programs.

The teacher also points out the importance of the students' autonomy to improve their English. Technology as a way to increase language use and more study hours were also mentioned. The participant recommends that the institution offer more extra-curricular activities to promote English learning in order to contribute to internationalization programs.

\section{CONCLUSION}

This paper shows what English language proficiency level is expected in the Sakura student exchange program offered by the JST and how it is seen by students and teacher of two classes of high school course integrated to technical programs in Automation and 
INDEPENDENT JOURNAL OF MANAGEMENT \& PRODUCTION (IJM\&P)

http://www.ijmp.jor.br

v. 12, n. 9, Special Edition, December 21, IFLOG 2020

ISSN: 2236-269X

DOI: 10.14807/ijmp.v12i9.1574

Chemistry. Such discussion has been encouraged due to the importance of internationalization actions in Brazilian educational institutions.

Results indicate that although some students can meet the English level required by the Japanese program, the majority of them are still at a lower level. Speaking and listening were identified as the main skills in JSP program and the former has been the most challenging one according to the students and the English teacher. Such situation eventually prevents students from submitting their applications.

Thus English teaching and learning should be more intensified if the investigated institution aims to broaden its internationalization process and increase students' chances to successfully take part in mobility program selections.

\section{REFERENCES}

Council of Europe. Council for Cultural Co-operation. Education Committee. Modern Languages Division. (2001). Common European Framework of Reference for Languages: learning, teaching, assessment. Cambridge: Cambridge University Press.

Crystal, D. (2003). English as a global language. Cambridge: Cambridge University Press. Cunha-Melo, J. R. D. (2015). Indicadores efetivos da internacionalização da ciência. Revista do Colégio Brasileiro de Cirurgiões, 42, 20-25.

De Wit, H., de Wit, J. H., Jaramillo, I. C., Gacel-Avila, J., \& Knight, J. (Eds.). (2005). Higher education in Latin America: The international dimension, (638). World Bank Publications.

De Wit, H., Hunter, F., Howard, L., \& Egron-Polak, E. (2015). Internationalisation of higher education. The Bloomsbury Handbook of the Internationalization of Higher Education in the Global South, 23, 328.

Finardi, K., \& Rojo, R. (2015). Globalization, Internationalization and Education: What is the Connection?. International E-Journal of Advances in Education, 1(1), 18-25.

Finardi, K. R., \& Tyler, J. (2015). The role of English and technology in the internationalization of education: insights from the analysis of MOOCs. In 7th international conference on education and new learning technologies, 11-18.

Firth, A. (1996). The discursive accomplishment of normality: On 'lingua franca'English and conversation analysis. Journal of pragmatics, 26(2), 237-259.

Fonseca, A. L. S. B. (2016). Inglês: a língua da internacionalização. Interfaces CientíficasEducação, 4(2), 23-32.

Kahane, H., \& Kahane, R. (1976). " Lingua Franca": The Story of a Term. Romance Philology, 30(1), 25-41.

Knight, J. (2003). Updated definition of internationalization. International higher education, (33), 2-3.

Ninomiya, A., Knight, J., \& Watanabe, A. (2009). The past, present, and future of internationalization in Japan. Journal of Studies in International Education, 13, 117-124. 
Pontes, V. D. F., \& Davel, M. A. N. (2016). O inglês na educação básica: um desafio para o professor. Revista X, Curitiba, 1, 102-117.

Seidlhofer, B. (2005). English as a lingua franca. ELT Journal, 59, 339-341

Trevisol, J. R. (2014). Dificuldades gerais de pronúncia para aprendizes brasileiros de inglês como língua estrangeira. Revista $\mathrm{X}, 1$.

UNESCO (1953). The Use of Vernacular Languages in Education. UNESCO, Paris. 